\title{
Growth kinetics of Salmonella Typhimurium and Listeria monocytogenes in buffalo milk under different processing and storage conditions
}

\author{
Joelson Sousa Lima ${ }^{1^{*}}$ (iD) Ana Paula Presley Oliveira Sampaio ${ }^{1}$ iD \\ Mylla Christy da Silva Dufossé ${ }^{1}$ (D) Paula Fernanda Morais de Sousa ${ }^{1}$ (D) \\ Josyane Brasil da Silva ${ }^{2}$ (iD) Carina Martins de Moraes ${ }^{1}$ (D) Talita Bandeira Roos ${ }^{1}$ (iD
}

\author{
${ }^{1}$ Instituto de Medicina Veterinária, Universidade Federal do Pará (UFPA), 68746-000, Castanhal, PA, Brasil. E-mail: joelsonbio@live.com. \\ ${ }^{*}$ Corresponding author. \\ ${ }^{2}$ Universidade do Estado do Pará (UEPA), Castanhal, PA, Brasil.
}

\begin{abstract}
Buffalo milk is rich in nutrients and can serve as a substrate for the proliferation of microorganisms. Thus, the objective of the present study was to evaluate the growth kinetics of Salmonella Typhimurium and Listeria monocytogenes in buffalo milk under different processing and storage conditions. Samples of raw and pasteurized milk were inoculated with 1 CFU of each bacterium, separately and together, per $25 \mathrm{~mL}$. After contamination, samples were stored at $8{ }^{\circ} \mathrm{C}$ or $37^{\circ} \mathrm{C}$, and bacterial counts were performed at 24 , 48 , and $168 \mathrm{~h}$. In addition, the accompanying microbiota growth, $\mathrm{pH}$, and the effect of these variables on the growth kinetics of microorganisms were monitored. The pathogens tested were able to proliferate under most conditions tested, reaching high titers throughout the experimental period. At 37 ${ }^{\circ} \mathrm{C}$, there was a decrease in $\mathrm{pH}$ and an increase in the accompanying microbiota that interfered with the microbial growth curve. It was also observed that pasteurized milk subjected to $8^{\circ} \mathrm{C}$ provided better conditions for the multiplication of bacteria. Therefore, it was concluded that care throughout the production chain, storage, and commercialization of milk must be adopted to guarantee the microbiological safety of this food.

Key words: food safety, pathogen modeling, food pathogens, dairy products.
\end{abstract}

Cinética de crescimento de Salmonella Typhimurium e Listeria monocytogenes em leite bubalino sob diferentes condições de processamento e armazenamento

RESUMO: O leite bubalino é rico em nutrientes e pode servir de substrato para a proliferação de micro-organismos. Assim, o objetivo do presente estudo foi avaliar a cinética de crescimento de Salmonella Typhimurium e Listeria monocytogenes em leite bubalino, em diferentes condições de processamento e armazenamento. Para isso, utilizaram-se amostras de leite cru e pasteurizado, que foram inoculadas com 1 UFC/25 mL de cada bactéria separadamente e em conjunto. Após a contaminação, as amostras foram armazenadas nas temperaturas de $8{ }^{\circ} \mathrm{C}$ e $37^{\circ} \mathrm{C}$ e realizadas contagens bacterianas em 24, 48 e 168h. Além disso, foi acompanhado o crescimento da microbiota acompanhante, o pH e o efeito dessas variáveis sobre a cinética de crescimento dos micro-organismos. Os patógenos testados conseguiram se proliferar na maioria das condições testadas, atingindo altos títulos durante todo o período experimental. Na temperatura de $37^{\circ} \mathrm{C}$, houve uma diminuição do pH e um aumento da microbiota acompanhante, o que interferiu na curva de crescimento microbiana. Observou-se também que o leite pasteurizado e submetido a $8{ }^{\circ} \mathrm{C}$ possibilitou melhores condições para a multiplicação das bactérias. Sendo assim, concluiu-se que cuidados durante toda a cadeia de produção, armazenamento e comercialização do leite devem ser adotados para garantir a segurança microbiológica desse alimento. Palavras-chave: segurança alimentar, modelagem de patógenos, patógenos alimentares, produtos lácteos.

\section{INTRODUCTION}

Buffalo milk has important nutritional properties, such as high protein levels and reduced cholesterol content, and has been shown to be beneficial for human consumption. For this reason, it has attracted the attention of consumers (PIGNATA et al., 2014), as well as commercial interest in using this raw material for the elaboration of several derivatives (BITTENCOURT et al.,
2013). These products can also serve as a substrate for the proliferation of pathogenic microorganisms, confirming the need to understand the kinetics of microbial growth in food.

Although, records on the incidence of pathogens such as Listeria monocytogenes and Salmonella spp. in buffalo milk are still incipient, it is known that, in general, dairy products are important vehicles for these bacteria (SONNIER et al., 2018; OBAIDAT \& STRINGER, 2019). 


\section{L. monocytogenes and Salmonella} enterica serotypes are pathogens commonly reported in outbreaks of foodborne diseases and are prevalent in various types of foods (BRASIL, 2019a; ARSLAN \& OZDEMIR, 2020). Both microorganisms represent a serious problem for public health because of the effects caused by infection. Thus, it is necessary to monitor the sources of contamination and the dissemination of these agents to ensure food quality and safety.

L. monocytogenes is a bacterium that is widely distributed in the environment and can survive over a wide temperature range (KUAN et al., 2013), able to withstand adverse conditions, survive in aggressive environments, and form biofilms, mainly in food processing facilities, which can cause contamination of several products (AMAJOUD et al., 2018). Bacteria of the genus Salmonella stand out in Brazil among the main etiological agents that cause food-borne infections (BRAZIL, 2019a). They are implicated in various clinical conditions such as typhoid fever, septicemia, and gastroenteritis, and may even lead to death in infected individuals (LI et al., 2017).

ARAI et al. (2020) pointed to Salmonella spp. as one of the main causes of gastroenteritis in both humans and animals, with the majority of salmonellosis in adult dairy cows caused by Salmonella Typhimurium. These animals can become reservoirs of bacteria and cause contamination of milk. Contamination by $S$. Typhimurium can also occur after pasteurization due to inadequate processing conditions and contact with raw milk (OLSEN et al., 2004). In addition, $S$. Typhimurium's resistance to antibiotics has frequently been noted, making its contamination even more worrying, since it can cause serious complications in clinical patients. (YANG et al., 2020). SAVRAN et al. (2018) demonstrated the survival capacity of this bacterium during the fermentation of milk, even with a low level of initial contamination, demonstrating that factors related to the survival capacity of $S$. Typhimurium may also favor the occurrence of cases and outbreaks involving the microorganism.

Many studies in the field of predictive microbiology have evaluated the growth and survival of bacteria in different food matrices (MALHEIROS et al., 2007; OHKOCHI et al., 2013; THOMAS et al., 2019). Given these studies, it is known that numerous factors influence the proliferation of microorganisms, such as temperature, $\mathrm{pH}$, water activity, and native microbiota (TIGANITAS et al., 2009; ZAHER \& FUJIKAWA, 2011). Thus, knowing the effect of these variables allows the establishment of control and prevention measures for food contamination, especially in milk, which is a nutrient-rich food that is widely consumed and often manipulated and stored in unsatisfactory conditions.

The objective of the present study was to evaluate the growth kinetics of $S$. Typhimurium and Listeria monocytogenes in raw and pasteurized buffalo milk subjected to different temperatures and storage times.

\section{MATERIALS AND METHODS}

A strain of $S$. Typhimurium (ATCC 14028) was grown in brain-heart infusion (BHI) broth for $18-24 \mathrm{~h}$ at $37^{\circ} \mathrm{C}$. After growth, purity was controlled using bacterioscopy and Gram staining. Subsequently, the bacterium was sown in solid medium on xylose lysine dexcolate (XLD) agar, striated on the surface, and cultivated at $37{ }^{\circ} \mathrm{C}$ for 18-24 $\mathrm{h}$ to obtain isolated colonies.

For L. monocytogenes, the strain ATCC 7644 was grown in BHI broth for $24-48 \mathrm{~h}$, at $37^{\circ} \mathrm{C}$ to obtain isolated colonies, and the bacteria were sown on PALCAM agar and cultivated under the same conditions mentioned above.

The milk samples used during the experiment were obtained from a rural property located in the municipality of Salvaterra, Archipelago of Marajó, Pará, through manual milking, under hygienic conditions. The milk was milked from four healthy and rested buffaloes, and the samples obtained were subsequently refrigerated to the Laboratory of Hygiene and Food Quality at the Federal University of Pará, campus of Castanhal, where the experiment was carried out from October 2019 to January 2020.

To execute the experiment, treatments were performed with raw and pasteurized milk, which were experimentally contaminated with $S$. Typhimurium and L. monocytogenes, individually and together. Samples of uncontaminated milk were used as negative controls. Experimental pasteurization was carried out using rapid pasteurization (high temperature, short time - HTST), with heating at $72{ }^{\circ} \mathrm{C}$ for $15 \mathrm{~s}$, followed by cooling to $4{ }^{\circ} \mathrm{C}$ (BRASIL, 2011). As for experimental contamination, the procedure was based on federal laws that impose restrictions on pathogenic microorganisms (BRASIL, 2001; BRASIL, 2019b) and on the state legislation for buffalo cheese (PARA, 2013), which determines the absence of $L$. monocytogenes and Salmonella spp. In $25 \mathrm{~g}$ of food, 1 colony forming unit (CFU) of the microorganisms was inoculated into $25 \mathrm{~mL}$ of milk from each treatment, 
with the aim of detecting the lowest microbial load that will likely cause contamination of the product.

Subsequently, in order to evaluate the time and temperature variables involved in the milk production and commercialization chain, some of the samples were kept in a refrigerator at $8{ }^{\circ} \mathrm{C}$, ideal for transport, storage, and delivery for consumption, as suggested (Brasil, 2018). The rest of the samples were incubated in an oven and subjected to a temperature of $37{ }^{\circ} \mathrm{C}$ to simulate failures that can occur in the proper packaging of the product.

Considering specific points in the milk production chain, which include transportation time, arrival at the establishments, start of sales, and shelf life, the concentration of each pathogen in the samples was verified through bacterial titration, as well as measuring the accompanying microbiota and $\mathrm{pH}$, at intervals of $0,24,48$, and $168 \mathrm{~h}$.

To count the bacteria of the accompanying microbiota, $1 \mathrm{~mL}$ of each sample was transferred to 9 $\mathrm{mL}$ of saline solution $(0.85 \%)$, and up to $10-15$ serial dilutions were made. Subsequently, $1 \mathrm{~mL}$ of each dilution was inoculated, by depth, into standard agar for counting (PCA), and the plates were incubated for $48 \mathrm{~h}$ at $37^{\circ} \mathrm{C}$ (BRASIL, 2003; SILVA et al., 2010).

Salmonella was titrated by performing up to 10-15 serial dilutions in saline solution, from which 0.1 aliquots were removed and inoculated on the surface of XLD agar by spreading with the aid of a Drigalsky loop. Plates were incubated at $37{ }^{\circ} \mathrm{C}$ for 18-24 $\mathrm{h}$. The same procedure was carried out for the titration of L. monocytogenes, and sowing was carried out on the surface of PALCAM agar.

Bacterial growth curves were compared with the models generated for each microorganism using the Pathogen Modeling Program from the United States Department of Agriculture (USDA), version 7.0. The parameters of average generation time $(\mathrm{G})$ and specific speed $(\mu)$ were also calculated from the values obtained between the exponential phase and the beginning of the stationary phase of growth. The equations for determining these variables, described by LEMOS et al. (1996), are described below. Average Generation Time (G)

$$
\begin{aligned}
& G=\frac{t}{3,322(\log N f-\log N i)} \\
& \text { Specific Growth Rate }(\mu) \\
& \mu=\frac{\ln N f-\ln N i}{\mathrm{t}}
\end{aligned}
$$

$\mathrm{t}=$ Time $(\min )$

$\mathrm{Ni}=$ Initial number of cells $\left(\right.$ UFC. $\left.\mathrm{mL}^{-1}\right)$

$\mathrm{Nf}=$ Final number of cells $\left(\mathrm{UFC} \cdot \mathrm{mL}^{-1}\right)$
During the experiment, 12 treatments were carried out, performed in triplicate with two repetitions, to ensure the highest reliability of the data generated, and 72 samples were analyzed. The data obtained in the replicates and repetitions of the experiment were tabulated and treated using descriptive statistics, adopting measures of central tendency (arithmetic mean) and variability (standard deviation).

\section{RESULTS AND DISCUSSION}

From contamination with $1 \mathrm{CFU}$ for each $25 \mathrm{~mL}$ of milk, an expressive microbial proliferation was obtained under most conditions tested, especially when the samples were kept at refrigerated temperatures. Unlike other studies in which higher doses were used for contamination, ranging from 2 to 4 $\log$ UFC (ZAHER \& FUJIKAWA, 2011; FUJIKAWA et al., 2015), in the present study, bacterial growth was observed even with a low initial inoculum.

When the material studied was stored at 37 ${ }^{\circ} \mathrm{C}$, it was possible to draw a complete growth curve for $S$. Typhimurium only when this bacterium was inoculated into pasteurized milk (Figure 1), with no proliferation of microorganisms in raw milk. At the same temperature $\left(37^{\circ} \mathrm{C}\right)$, L. monocytogenes was unable to establish itself in the food until the end of the test period, since both in raw and pasteurized milk, the pathogen only grew up to $24 \mathrm{~h}$. The lack of growth or non-persistence of these pathogens may have occurred mainly due to competition with the accompanying microbiota, which had concentration variations from 9 to $11 \log$ UFC.mL-1, and/or due to acidification of the medium, which was more accentuated at $37^{\circ} \mathrm{C}$, where $\mathrm{pH}$ values of 4.23 , were recorded in the treatment with $S$. Typhimurium and 3.8 in milk with L. monocytogenes (Table 1).

Conversely, when the temperature of $8{ }^{\circ} \mathrm{C}$ was used for the incubation of the samples, both tested microorganisms grew in both raw and pasteurized milk (Figure 2). However, when the two bacteria were inoculated together in the food, both grew at a temperature of $8{ }^{\circ} \mathrm{C}$ in raw and pasteurized milk (Figure $2 \mathrm{E}$ and $\mathrm{F}$ ). This demonstrated the possibility of mixed contamination by these pathogens in buffalo milk, since one microorganism does not significantly alter the proliferation of the other.

It is known that L. monocytogenes can survive in adverse conditions for long periods, including low temperatures (OHKOCHI et al., 2013; THOMAS et al., 2019). However, it has been reported that the growth of Salmonella bacteria is affected or inactivated at temperatures below $8{ }^{\circ} \mathrm{C}$ 


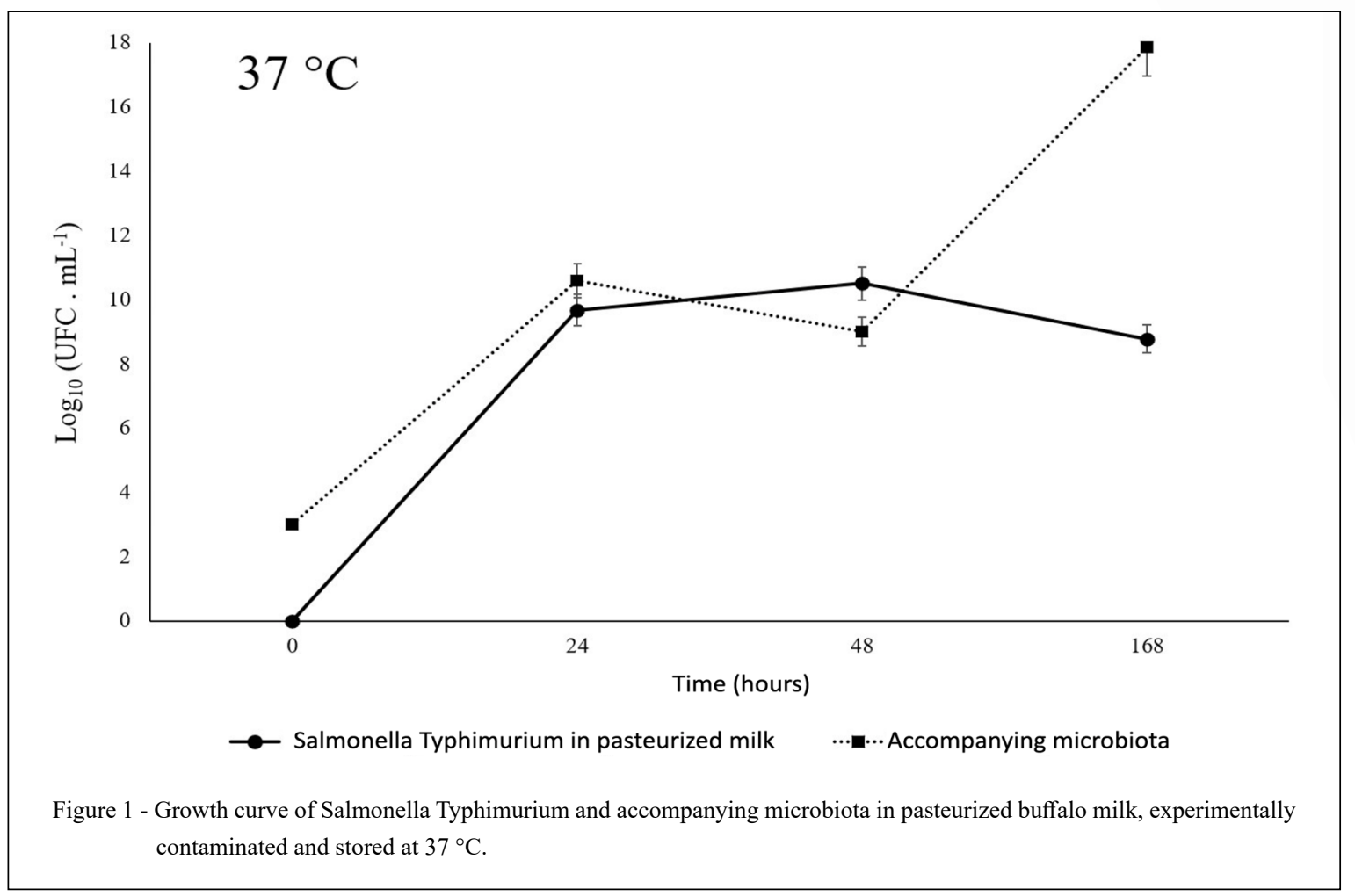

(MALHEIROS et al., 2007; TIGANITAS et al., 2009; ZAHER \& FUJIKAWA, 2011; JIA et al., 2020). Our results showed a good ability of this pathogen to develop even under refrigeration conditions, and this information should be considered in future studies that consider the agent as a target.

Our results also showed that, when microorganisms established themselves in the food in different forms of processing and storage, high concentrations of pathogens were sustained until the end of the experiment; during the period of storage, bacteria may be viable in titers compatible with infectious doses. According to HUMPHREY (2004), the infective dose of Salmonella spp. for healthy humans varies between $10^{6}$ to $10^{8} \mathrm{CFU}$, although it has been reported that infections can occur with lower doses (MALHEIROS et al., 2007). In the present study, this dose was reached or even exceeded after $24 \mathrm{~h}$ of storage. However, for $L$. monocytogenes, the infectious dose is not known or accurately determined for the occurrence of outbreaks and disease manifestation; this depends on factors such as the host's immune response and virulence (TOURDJMAN et al., 2014).
We also observed that the $\mathrm{pH}$ of the milk at a temperature of $8{ }^{\circ} \mathrm{C}$ remained stable in relation to incubation at $37^{\circ} \mathrm{C}$. Table 1 shows the $\mathrm{pH}$ values, where it is possible to observe the variations in this parameter. The smallest measurements recorded occurred in raw milk subjected to a temperature of $37^{\circ} \mathrm{C}$, with $168 \mathrm{~h}$ of cultivation. Under these conditions, a pH of 3.28 was calculated for milk with $S$. Typhimurium, 3.38 for food inoculated with $L$. monocytogenes, and 3.32 for co-cultivation. These $\mathrm{pH}$ values may have occurred due to the accumulation of products of bacterial metabolism that acidify the medium, especially fermenting microorganisms from the accompanying microbiota.

TIGANITAS et al. (2009), when evaluating the effect of $\mathrm{pH}$ on bacterial growth, found that $L$. monocytogenes is more resistant than $S$. Typhimurium, which can be inactivated at $\mathrm{pH}$ levels below 4. From the same perspective, THOMAS et al. (2019) predicted the growth of $L$. monocytogenes in fresh cheese stored at temperatures ranging from 4 to $30{ }^{\circ} \mathrm{C}$. The initial $\mathrm{pH}$ values of the milk were 6.74 , and at all temperatures, the $\mathrm{pH}$ decreased over time, more rapidly at temperatures of $15-30{ }^{\circ} \mathrm{C}$ 
Table $1-\mathrm{pH}$ values obtained from raw and pasteurized buffalo milk, inoculated with Salmonella Typhimurium and Listeria monocytogenes, stored at temperatures of $8^{\circ} \mathrm{C}$ and $37^{\circ} \mathrm{C}$.

\begin{tabular}{|c|c|c|c|c|c|}
\hline & \multirow[b]{2}{*}{ Time } & \multicolumn{2}{|c|}{----------------------8 C----------------------- } & \multicolumn{2}{|c|}{ 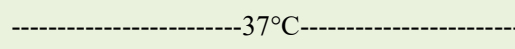 } \\
\hline & & $\begin{array}{l}\text { Raw milk } \\
\mathrm{X} \pm \mathrm{SD}^{*}\end{array}$ & $\begin{array}{l}\text { Pasteurized Milk } \\
\qquad \mathrm{X} \pm \mathrm{SD}\end{array}$ & $\begin{array}{c}\text { Raw milk } \\
\mathrm{X} \pm \mathrm{SD}\end{array}$ & $\begin{array}{l}\text { Pasteurized Milk } \\
\qquad \mathrm{X} \pm \mathrm{SD}\end{array}$ \\
\hline \multirow{4}{*}{$\begin{array}{l}\text { Salmonella } \\
\text { Typhimurium }\end{array}$} & $0 \mathrm{~h}$ & $6.80 \pm 0.01$ & $6.80 \pm 0.01$ & $6.80 \pm 0.20$ & $6.80 \pm 0.63$ \\
\hline & $24 \mathrm{~h}$ & $6.31 \pm 0.50$ & $6.66 \pm 0.01$ & $4.23 \pm 1.00$ & $5.69 \pm 0.05$ \\
\hline & $48 \mathrm{~h}$ & $6.14 \pm 1.00$ & $6.63 \pm 0.20$ & $3.79 \pm 0.20$ & $4.28 \pm 1.00$ \\
\hline & $168 \mathrm{~h}$ & $5.48 \pm 0.20$ & $6.18 \pm 0.05$ & $3.28 \pm 0.50$ & $3.61 \pm 1.00$ \\
\hline \multirow{4}{*}{ Listeria monocytogenes } & $\mathrm{Oh}$ & $6.80 \pm 0.17$ & $6.80 \pm 1.00$ & $6.80 \pm 0.02$ & $6.80 \pm 0.02$ \\
\hline & $24 \mathrm{~h}$ & $6.29 \pm 0.01$ & $6.69 \pm 0.10$ & $4.18 \pm 0.42$ & $4.38 \pm 1.00$ \\
\hline & $48 \mathrm{~h}$ & $6.17 \pm 0.07$ & $6.59 \pm 0.10$ & $3.80 \pm 0.50$ & $4.25 \pm 1.17$ \\
\hline & $168 \mathrm{~h}$ & $5.65 \pm 1.17$ & $6.37 \pm 0.50$ & $3.38 \pm 0.57$ & $3.75 \pm 0.05$ \\
\hline \multirow{4}{*}{ Co-cultivation } & $0 \mathrm{~h}$ & $6.80 \pm 0.01$ & $6.80 \pm 0.01$ & $6.80 \pm 0.57$ & $6.80 \pm 0.01$ \\
\hline & $24 \mathrm{~h}$ & $6.32 \pm 0.50$ & $6.68 \pm 0.01$ & $4.31 \pm 0.05$ & $4.43 \pm 1.00$ \\
\hline & $48 \mathrm{~h}$ & $6.06 \pm 1.00$ & $6.59 \pm 0.10$ & $3.85 \pm 1.00$ & $4.25 \pm 0.01$ \\
\hline & $168 \mathrm{~h}$ & $5.50 \pm 1.15$ & $6.46 \pm 1.15$ & $3.32 \pm 1.00$ & $3.58 \pm 0.05$ \\
\hline
\end{tabular}

${ }^{*} \mathrm{X}=$ Arithmetic average; $\mathrm{SD}=$ Standard deviation.

than at $4^{\circ}-10{ }^{\circ} \mathrm{C}$. These authors showed that higher temperatures favor the fermentation of carbohydrates by microorganisms, thereby acidifying the medium. This information is in accordance with the results presented here, where it is noted that, especially at the highest temperature, the $\mathrm{pH}$ also dropped rapidly.

Competitive microbiota also have an adverse effect on the proliferation of pathogens. According to JIA et al. (2020), the growth of Salmonella spp. under conditions of competition with native microbiota can be inhibited. These authors observed that microbiota microorganisms are capable of growing in a wide temperature range, from 1.3-1.8 ${ }^{\circ} \mathrm{C}$ to $33{ }^{\circ} \mathrm{C}$, and that the growth rate of Salmonella spp. may be smaller or larger than that of the native microbiota, depending on the storage temperature. Likewise, ZAHER \& FUJIKAWA (2011) evaluated the growth kinetics of $S$. Enteretidis in sterilized chicken and in raw ground chicken with high and low levels of native microbiota; this group realized that in the sterile product, under ideal conditions and without competitors, the growth of the pathogen occurs in an unimpeded way.

The data obtained here are consistent with those of the aforementioned authors. When the milk was pasteurized, the growth of both bacteria was optimized due to the reduction of the native microbiota, whereas in raw milk, an inverse relationship was observed between the growth of the accompanying microbiota and that of the pathogens. Indeed, pasteurization is a very efficient method for the elimination of pathogenic microorganisms from milk and is part of the quality control of this food. However, care after thermal processing must be carefully adopted, since this product in these conditions can allow the spread of infectious agents.

In the present study, the generation time calculated for $S$. Typhimurium varied from 0.62 to $0.71 \mathrm{~h}$ and that of L. monocytogenes from 0.60 to $0.68 \mathrm{~h}$, as can be seen in Table 2. The generation time of L. monocytogenes was shorter than that of $S$. Typhimurium, especially in raw milk stored at $8{ }^{\circ} \mathrm{C}$, which had the shortest time. In general, generation times between the bacteria were very close to each other, especially in treatments where the microorganisms were inoculated together (cocultivation), indicating that these pathogens can proliferate simultaneously.

Table 3 contains data relating to the specific speed of multiplication of pathogens, where the lowest values were $0.96 \log \left(\mathrm{UFC} . \mathrm{mL}^{-1}\right) / \mathrm{h}$ for both bacteria, and the maximum values were 1.14 


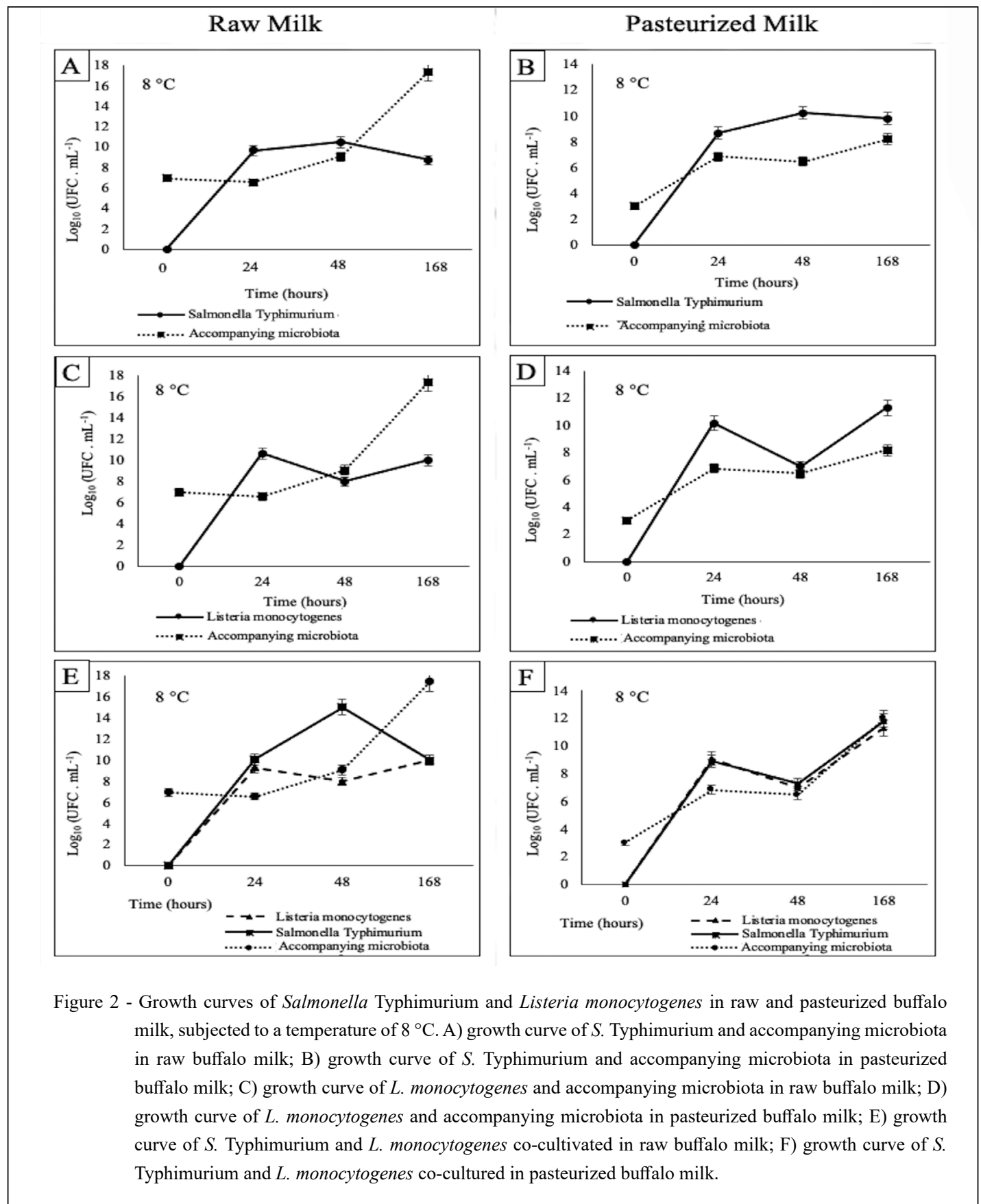

$\log \left(\mathrm{CFU} . \mathrm{mL}^{-1}\right) / \mathrm{h}$ for L. monocytogenes and $1.08 \mathrm{log}$ (UFC.mL ${ }^{-1}$ )/h for $S$. Typhimurium. L. monocytogenes multiplied more quickly than $S$. Typhimurium, mainly in raw milk at a temperature of $8{ }^{\circ} \mathrm{C}$, since it is a psychotrophic microorganism, which guarantees better conditions for its proliferation.

Data from USDA pathogen modeling showed that $L$. monocytogenes reached titers ranging between 4 and $5 \log$ UFC when incubated at $8{ }^{\circ} \mathrm{C}$ in culture medium. However, in the present study, it was observed that the concentration of this microorganism was higher, even though the initial inoculum was lower than that modeled by the program. Generation time at refrigeration temperatures tended to be longer, which is also in line with our results. Also according to these projections, the generation time at $37{ }^{\circ} \mathrm{C}$ would be $0.56 \mathrm{~h}$, and the microbial titer would be about 9.4 to $9.5 \log$ UFC.

Ciência Rural, v.51, n.11, 2021. 
Table 2 - Generation time (G), in hours, of Salmonella Typhimurium and Listeria monocytogenes in raw and pasteurized buffalo milk, stored at temperatures of $8{ }^{\circ} \mathrm{C}$ and $37^{\circ} \mathrm{C}$.

\begin{tabular}{|c|c|c|c|c|}
\hline & $\begin{array}{l}\text { Raw Milk } \\
\mathrm{X} \pm \mathrm{SD}^{*}\end{array}$ & $\begin{array}{l}\text { Pasteurized Milk } \\
\qquad \mathrm{X} \pm \mathrm{SD}\end{array}$ & $\begin{array}{c}\text { Raw Milk } \\
\mathrm{X} \pm \mathrm{SD}\end{array}$ & $\begin{array}{c}\text { Pasteurized Milk } \\
\qquad \mathrm{X} \pm \mathrm{SD}\end{array}$ \\
\hline Salmonella Typhimurium & $0.65 \mathrm{~h} \pm 0.001$ & $0.71 \mathrm{~h} \pm 0.015$ & $\mathrm{n} / \mathrm{g}^{* *}$ & $0.65 \mathrm{~h} \pm 0.005$ \\
\hline Listeria monocytogenes & $0.60 \mathrm{~h} \pm 0.011$ & $0.62 \mathrm{~h} \pm 0.005$ & $0.65 \mathrm{~h} \pm 0.020$ & $0.62 \mathrm{~h} \pm 0.010$ \\
\hline \multicolumn{5}{|c|}{ - } \\
\hline Salmonella Typhimurium & $0.62 \mathrm{~h} \pm 0.020$ & $0.70 \mathrm{~h} \pm 0.050$ & $0.70 \mathrm{~h} \pm 0.050$ & $0,62 \mathrm{~h} \pm 0.020$ \\
\hline Listeria monocytogenes & $0.63 \mathrm{~h} \pm 0.010$ & $0.68 \mathrm{~h} \pm 0.005$ & $0.65 \mathrm{~h} \pm 0.060$ & $0.68 \mathrm{~h} \pm 0.040$ \\
\hline
\end{tabular}

${ }^{*} \mathrm{X}=$ Arithmetic average; $\mathrm{SD}=$ Standard deviation.

${ }^{* *} \mathrm{n} / \mathrm{g}$ : No Growth - when there was no growth of the microorganism in the sample that would make it possible to calculate the generation time.

For $S$. Typhimurium, it was only possible to model the growth by obtaining ground chicken meat and incubating at a temperature of $10{ }^{\circ} \mathrm{C}$, at which the maximum growth of $2.32 \mathrm{log} \mathrm{CFU} / \mathrm{g}$ and a generation time of $6.36 \mathrm{~h}$ were calculated. Conversely, at $37{ }^{\circ} \mathrm{C}$, the generation time reduces to $0.79 \mathrm{~h}$, and the growth can reach levels of 8-10 $\log \mathrm{UFC} / \mathrm{g}$. However, in the present study, higher concentrations of bacteria were registered even at lower temperatures, and the generation times are very close to those calculated here.

MALHEIROS et al. (2007) analyzed the growth of Salmonella spp. strains inoculated in culture medium and in potato salad with mayonnaise. In the culture medium, at $30^{\circ} \mathrm{C}$, the bacterial titer was $8 \log$ UFC, and in the food, $6 \log$ UFC. However, at $9.5{ }^{\circ} \mathrm{C}$, there was no growth. At $30{ }^{\circ} \mathrm{C}$ in their work, the generation time was $0.69 \mathrm{~h}$, and the specific growth rate was $0.44 \mathrm{log} / \mathrm{h}$, in accordance with the data of the present study.

Control measures in the manufacture of dairy products are essential to prevent contamination by microorganisms from animal or environmental sources (POPPE, 2020). KEBA et al. (2020) indicated the prevalence of Salmonella spp. and L. monocytogenes in dairy foods and raw milk and explained that the adoption of hygiene practices at all stages of the chain is essential to avoid the incidence of these pathogens in dairy products. In this way, the risk of infections or outbreaks of diseases can be reduced.

Table 3 - Specific multiplication speed $(\mu)$, expressed in $\log$ UFC. $\mathrm{mL}^{-1} / \mathrm{h}$, of Salmonella Typhimurium and Listeria monocytogenes in raw and pasteurized buffalo milk, stored at temperatures of $8^{\circ} \mathrm{C}$ and $37^{\circ} \mathrm{C}$.

\begin{tabular}{lcccc}
\hline & Raw milk & Pasteurized milk & Raw milk & Pasteurized milk \\
& $\mathrm{X} \pm \mathrm{SD}^{*}$ & $\mathrm{X} \pm \mathrm{SD}$ & $\mathrm{X} \pm \mathrm{SD}$ & $\mathrm{X} \pm \mathrm{SD}$ \\
\hline Salmonella Typhimurium & $1.02 \log / \mathrm{h}^{* *} \pm 0.020$ & $0.96 \log / \mathrm{h} \pm 0.001$ & $\mathrm{n} / \mathrm{g}^{* * *}$ & $1.02 \log / \mathrm{h} \pm 0.005$ \\
Listeria monocytogenes & $1.14 \log / \mathrm{h} \pm 0.001$ & $1.08 \log / \mathrm{h} \pm 0.001$ & $1.02 \log / \mathrm{h} \pm 0.105$ & $1.08 \log / \mathrm{h} \pm 0.005$ \\
\hline Salmonella Typhimurium & $1.08 \log / \mathrm{h} \pm 0.050$ & $0.96 \log / \mathrm{h} \pm 0.50$ & $0.96 \log / \mathrm{h} \pm 0.010$ & $1.08 \log / \mathrm{h} \pm 0.503$ \\
Listeria monocytogenes & $1.02 \log / \mathrm{h} \pm 0.030$ & $0.96 \log / \mathrm{h} \pm 0.010$ & $1.02 \log / \mathrm{h} \pm 0.011$ & $0.96 \log / \mathrm{h} \pm 0.050$ \\
\hline
\end{tabular}

"X= Arithmetic average; $\mathrm{SD}=$ Standard deviation

${ }^{*} \log \left(\mathrm{UFC} / \mathrm{mL}^{-1}\right) / \mathrm{h}$

*** $\mathrm{n} / \mathrm{g}$ : No Growth - when there was no growth of the microorganism in the sample. 
Several factors, such as thermal treatment (pasteurization), $\mathrm{pH}$, humidity, concentration of organic acids, and the accompanying microbiota can inhibit the growth of bacteria in dairy products. However, if good hygiene practices are not applied preventively, the food can be contaminated after processing (TIRLONI et al., 2019), during transportation, storage, and marketing, causing risks to consumers, since even in pasteurized products and at refrigeration temperatures, these bacteria can potentially proliferate.

\section{CONCLUSION}

High titers of Salmonella Typhimurium and Listeria monocytogenes can result from contamination of buffalo milk, and both bacteria can grow together on this substrate. Under refrigeration, the $\mathrm{pH}$ reduction was slowed, while incubation at $37{ }^{\circ} \mathrm{C}$ allowed the proliferation of the accompanying microbiota and acidification of the medium, which interfered with the growth of the two studied bacteria. In addition, in pasteurized milk, with fewer competing microorganisms, the growth of pathogens was enhanced; therefore, care after the thermal processing of milk is necessary.

\section{ACKNOWLEDGEMENTS}

We thank the Coordenação de Aperfeiçoamento de Pessoal de Nível Superior - Brasil (CAPES) for providing a scholarship to Joelson Sousa Lima, Ana Paula Presley Oliveira Sampaio and Mylla Christy da Silva Dufossé.

\section{DECLARATION OF CONFLICT OF INTEREST}

The authors declare no conflict of interest. The founding sponsors had no role in the design of the study; in the collection, analyses, or interpretation of data; in the writing of the manuscript, and in the decision to publish the results.

\section{AUTHORS' CONTRIBUTIONS}

All authors contributed equally for the conception and writing of the manuscript. All authors critically revised the manuscript and approved of the final version.

\section{REFERENCES}

AMAJOUD, N. et al. Prevalence of Listeria spp. and characterization of Listeria monocytogenes isolated from food products in Tetouan, Morocco. Food Control, v. 84, p. 436-441, 2018. Available from: $<$ https://doi.org/10.1016/j.foodcont.2017.08.023>. Accessed: 26 oct. 2020. doi: 10.1016/j.foodcont.2017.08.023.

ARAI, N. et al. Phylogenetic characterization of Salmonella enterica serovar Typhimurium and its monophasic variant isolated from food animals in Japan revealed replacement of major epidemic clones in the last 4 decades. Journal of clinical microbiology, v.56, n.5, e 0175817, 2018. Available from: <https://doi.org/10.1128/JCM.01758-17>. Accessed: 09 feb. 2021. doi: 10.1128/JCM.01758-17.

ARSLAN, S.; ÖZDEMIR, F. Prevalence and antimicrobial resistance of Listeria species and molecular characterization of Listeria monocytogenes isolated from retail ready-to-eat foods. FEMS Microbiology Letters, v. 367, n. 4, 2020. Available from: $<$ https://doi. org/10.1093/femsle/fnaa006>. Accessed: 26 oct. 2020. doi: 10.1093/ femsle/fnaa006.

BITTENCOURT, R. H. F. P. et al. Caracterização de requeijão marajoara e minas frescal produzidos com leite de búfalas no Estado do Pará, Brasil. Ciência Rural, v. 43, n. 9, p. 1687-1692, 2013. Available from: $<$ https://doi.org/10.1590/S0103-84782013005000110>. Accessed: 26 oct. 2020. doi: 10.1590/S0103-84782013005000110.

BRASIL. MINISTÉRIO DA SAÚDE. Surto de doenças transmitidas por alimentos no Brasil. Manual integrado de vigilância, prevenção e controle de Doenças transmitidas por alimentos. 2019a. Disponível em: <http://bvms.saude.gov.br/bvs/publicacoes/ manual_integrado_vigilancia_doencas_alimentos.pdf $>$.

BRASIL. Agência Nacional de Vigilância Sanitária. 2019b. Instrução Normativa n. 60, de 23 de dezembro de 2019. Diário Oficial da União, Brasília, DF, 26 dez. 2019. Available from: $<$ https:/www.in.gov.br/web/dou/-/instrucao-normativa-n-60-de23-de-dezembro-de-2019-235332356>. Accessed: 06 feb. 2021

BRASIL. Ministério da Agricultura, Pecuária e Abastecimento. 2018. Instrução Normativa n. 76, de 26 de novembro de 2018. Diário Oficial da União, Brasília, DF, 30 nov. 2018. Available from: <https:// www.in.gov.br/materia/-/asset_publisher/Kujrw0TZC2Mb/content/ id/52750137/do1-2018-11-30-instrucao-normativa-n-76-de-26-denovembro-de-2018-52749894IN\%2076>. Accessed: 06 feb. 2021

BRASIL. Ministério da Agricultura, Pecuária e Abastecimento. 2011. Instrução Normativa n. 62, de 29 de dezembro de 2011. Diário Oficial da União, Brasília, DF, 30 dez. 2011. Available from: <https://www. apcbrh.com.br/files/IN62.pdf >. Accessed: 30 jan. 2021.

BRASIL. Ministério da Agricultura, Pecuária e Abastecimento. 2003. Instrução Normativa n. 62 de 26 de agosto de 2003. Oficializa os métodos analíticos oficiais para análises microbiológicas para controle de produtos de origem animal e água. Diário Oficial da União, Brasília, DF, 18 agos. 2003. Available from: $<$ https://www. defesa.agricultura.sp.gov.br/legislacoes/instrucao-normativa-sda62-de-26-08-2003,665.html>. Acessed: 06 feb. 2021.

BRASIL. Agência Nacional de Vigilância Sanitária. 2001. Resolução no 12 , de 2 de janeiro de 2001. Regulamento técnico sobre os padrões microbiológicos para alimentos. Diário Oficial da União, Brassília, DF. Available from: $<$ http://www.anvisa.gov.br>. Accessed: 30 jan. 2021.

FUJIKAWA, H. et al. Prediction of the growth of Salmonella Enteritidis in raw ground beef at various combinations of the initial concentration of the pathogen and temperature. Biocontrol Science, v. 20, n. 3, p. 215-220, 2015. Available from: $<$ https://doi. org/10.4265/bio.20.215>. Accessed: 26 oct. 2020. doi: 10.4265/ bio. 20.215 .

HUMPHREY, T. J. Salmonella, stress responses and food safety. Science and Society, v. 2, n. 6, p. 504-509, 2004. Available from: $<$ https://doi.org/10.1038/nrmicro907>. Accessed: 26 oct. 2020. doi: 10.1038/nrmicro907. 
JIA, Z. et al. One-step kinetic analysis of competitive growth of Salmonella spp. 1 and background flora in ground chicken. Food Control, v. 117, p. 1-11, 2020. Available from: <https://doi. org/10.1016/j.foodcont.2020.107103>. Accessed: 26 oct. 2020. doi: 10.1016/j.foodcont.2020.107103.

KEBA, A. et al. Review of the prevalence of foodborne pathogens in milk and dairy products in Ethiopia. Int Dairy J., v.109, 104762, 2020. Available from: <https://doi.org/10.1016/j. idairyj.2020.104762>. Accessed: 10 feb. 2021. doi: 10.1016/j. idairyj.2020.104762.

KUAN, C. H. et al. Prevalence and quantification of Listeria monocytogenes in beef offal at retail level in Selangor, Malaysia. Brazilian Journal of Microbiology, v. 44, n. 4, p. 11691172, 2013. Available from: <https://doi.org/10.1590/S1517$83822014005000002>$. Accessed: 26 oct. 2020 . doi: $10.1590 /$ S1517-83822014005000002.

LEMOS, W. P. C. Manual de laboratório de tecnologia bioquímica. Porto Alegre: UFRGS, 1996. 225 p.

LI, F. et al. Sextuplex PCR combined with immunomagnetic separation and PMA treatment for rapid detection and specific identification of viable Salmonella spp., Salmonella enterica serovars Paratyphi B, Salmonella Typhimurium, and Salmonella Enteritidis in raw meat. Food Control, v. 73, p. 587-594, 2017. Available from: $<$ https://doi.org/10.1016/j.foodcont.2016.09.009>. Accessed: 26 oct. 2020. doi: 10.1016/j.foodcont.2016.09.009.

MALHEIROS, P. da S. et al. Cinética de crescimento de Salmonella Enteritidis envolvida em surtos alimentares no RS: uma comparação com linhagens de outros sorovares. Ciência e Tecnologia de Alimentos, v. 27, n.4, p.751-755, 2007. Available from: $\quad<$ https://doi.org/10.1590/S0101-20612007000400013>. Accessed: 26 oct. 2020. doi: 10.1590/S0101-20612007000400013.

OBAIDAT, M. M.; STRINGER, A. P. Prevalence, molecular characterization, and antimicrobial resistance profiles of Listeria monocytogenes, Salmonella enterica, and Escherichia coli O157:H7 on dairy cattle farms in Jordan. Journal of Dairy Science, v. 102, n. 10, p. 8710-8720, 2019. Available from: $<$ https://doi.org/10.3168/jds.2019-16461>. Accessed: 26 oct. 2020. doi: $10.3168 /$ jds.2019-16461.

OHKOCHI, M. et al. Growth modeling of Listeria monocytogenes in pasteurized liquid egg. Journal of Food Protection, v. 76, n. 9, p.1549-1556, 2013. Available from: $<$ https://doi.org/10.4315/0362028X.JFP-12-524>. Accessed: 26 oct. 2020. doi: 10.4315/0362028X.JFP-12-524

OLSEN, S. J. et al. Multidrug-resistant Salmonella Typhimurium infection from milk contaminated after pasteurization. Emerg Infect Dis, v.10, n.5, p.932-5, 2004. Available from: <https:// doi.org/10.3201/eid1005.030484>. Accessed: 08 feb. 2021. doi: $10.3201 /$ eid 1005.030484

PARA. Agência Estadual de Defesa Agropecuária do Estado do Pará. 2013. Portaria n. 0418 de 04 de março de 2013. Regulamento técnico de produção do queijo do Marajó. Available from: <http://www.adepara.pa.gov.br/sites/default/files/ PORTARIA $\% 20 \mathrm{~N} \% \mathrm{C} 2 \%$ BA $\% 20418-2013 \% 20-\% 20$ Queijo $\% 20$ do\%20Maraj\%C3\%B3.pdf>. Accessed: 06 feb. 2021.

PIGNATA, M. C. et al. Estudo comparativo da composição química, ácidos graxos e colesterol de leites de búfala e vaca.
Revista Caatinga, v. 27, n. 4, p. 226-233, 2014. Available from: $<$ https://periodicos.ufersa.edu.br/index.php/caatinga/article/ view/3228\#: :text=Apesar\%20de\%20apresentar\%20maior $\% 20$ teor,vaca $\% 20$ apresentaram $\% 20$ qualidade $\% 20$ nutricional $\% 20$ adequada $>$. Accessed: 26 oct. 2020

POPPE, C. Pathogens in milk: Salmonella spp., reference module in food science, Elsevier, 2020. Available from: $<$ https://doi. org/10.1016/B978-0-08-100596-5.22968-5>. Accessed: 10 feb. 2021. doi: 10.1016/B978-0-08-100596-5.22968-5.

SAVRAN D. et al. Modeling the survival of Salmonella Enteritidis and Salmonella Typhimurium during the fermentation of yogurt. Food Sci Technol Int., v. 24, n.2, p.110-116, 2018. Available from: $<$ https://doi.org/10.1177/1082013217734089>. Acessed: 08 feb. 2021. doi: $10.1177 / 1082013217734089$

SILVA, N. et al. Manual de métodos de análise microbiológica de alimentos e água. 4. ed. São Paulo: Varela editora, 2010, 624p.

SONNIER, J. L. et al. Prevalence of Salmonella enterica, Listeria monocytogenes, and pathogenic Escherichia coli in bulk tank milk and milk filters from US dairy operations in the National Animal Health Monitoring System Dairy 2014 study. Journal of Dairy Science, v. 101, n. 3, p.1943-1956, 2018. Available from: <https:// doi.org/10.3168/jds.2017-13546>. Accessed: 26 oct. 2020. doi: $10.3168 /$ jds.2017-13546.

THOMAS, M. Predictive model of Listeria monocytogenes growth in queso Fresco. Journal of Food Protection, v. 82, n. 12, p. 2071-2079, 2019. Available from: <https://doi.org/10.4315/0362028X.JFP-19-185>. Accessed: 26 oct. 2020. doi: 10.4315/0362028X.JFP-19-185.

TIGANITAS, A. et al. Study of the effect of lethal and sublethal $\mathrm{pH}$ and aw stresses on the inactivation or growth of Listeria monocytogenes and Salmonella Typhimurium. International Journal of Food Microbiology, v. 134, p. 104-112, 2009. Available from: $\quad<$ https://doi.org/10.1016/j.ijfoodmicro.2009.02.016> Accessed: 26 oct. 2020. doi: 10.1016/j.ijfoodmicro.2009.02.016.

TIRLONI, E. et al. Potential growth of Listeria monocytogenes in Italian mozzarella cheese as affected by microbiological and chemicalphysical environment. J Dairy Sci., 2019 v.02, n.6, p.4913-4924, 2019. Available from: <https://doi.org/10.3168/jds.2018-15991>. Accessed: 10 feb. 2021. doi: 10.3168/jds.2018-15991.

TOURDJMAN, M. et al. Listériose humaine: Une zoonose d'origine alimentaire Human listeriosis: a foodborne zoonotic disease. Revue Francophone des Laboratoires. v. 2014, n. 464, p. 37-44, 2014. Available from: <https://doi.org/10.1016/S1773035X(14)72573-0>. Accessed: 26 oct. 2020. doi: 10.1016/S1773035X(14)72573-0.

YANG, C. et al. Study on antibiotic susceptibility of Salmonella typhimurium $\mathrm{L}$ forms to the third and forth generation cephalosporins. Sci Rep., v.10, n.1, 3042, 2020. Available from: $<$ https://doi.org/10.1038/s41598-020-59456-8>. Acessed: 08 feb. 2021. doi: 10.1038/s41598-020-59456-8.

ZAHER, S. M.; FUJIKAWA, H. Effect of native microflora on the growth kinetics of Salmonella Enteritidis strain 04-137 in raw ground chicken. Journal of Food Protection, v. 74, n. 5, p. 735742, 2011. Available from: <https://doi.org/10.4315/0362-028X. JFP-10-334>. Accessed: 26 oct. 2020. doi: 10.4315/0362-028X. JFP-10-334. 